\title{
DIVERSITY AND GENETIC STRUCTURE OF NATURAL POPULATIONS OF ARAÇÁ (Psidium guineense Sw.) ${ }^{1}$
}

\author{
EDSON FERREIRA DA SILVA ${ }^{2 *}$, RAFAELA LIMA DE ARAÚJO², CRISTINA DOS SANTOS RIBEIRO MARTINS ${ }^{2}$, \\ LUIZA SUELY SEMEN MARTINS ${ }^{2}$, ELIZABETH ANN VEASEY ${ }^{3}$
}

\begin{abstract}
ABSTRAT - Psidium guineense Sw, popularly known as araçá, is a fruit tree there is widely distributed in Brazil and belongs to the Myrtaceae family. In northeastern Brazil, araçá occurs along coast and in the Zona da Mata; its fruit looks like guava but is more acidic and has a stronger smell. There is a little information about this species, which increases the difficulty of conserving its genetic resources and exploiting araçá as an economic resource. The objective of this research was the evaluation of the genetic diversity and genetic structure of $P$. guineense from Pernambuco's Zona da Mata. One hundred and fourteen individuals and 18 isozyme loci were evaluated, showing 28 alleles. The percentage of polymorphic loci $(\hat{P})$ and the average number of alleles per locus $(\hat{A})$ were 0.5 and 1.5 , respectively, in this population. The expected heterozygosity $\left(\hat{H}_{\theta}\right)$, which corresponds to the genetic diversity, ranged from 0.22 to 0.23 , a high value when considering that isozymes mark access from the functional genome. The differentiation index among the population was $\left(\widehat{\theta}_{p}\right)=$ 0.015; therefore, the populations were not different among the sampled places. The inbreeding values (f) ranged from -0.549 to -0.794 , indicating an absence of inbreeding and a greater-than-expected heterozygosity in all the studied populations. The estimated gene flow $\left(N_{m}\right)$ for a pair of this population ranged from 3.23 to 20.77 , sufficient to avoid genetic differentiation among the population and in accordance with the values of genetic divergence found in this study.
\end{abstract}

Keywords: Genetic resource. Isozyme. Native fruit. Gene flow.

\section{DIVERSIDADE E ESTRUTURA GENÉTICA DE POPULAÇÕES NATURAIS DE ARAÇÁ (Psidium guineense Sw.)}

RESUMO - Psidium guineense Sw., conhecida popularmente como araçá, é uma fruteira pertencente à família Myrtaceae que tem ampla distribuição geográfica. Nos Estados do Nordeste Brasileiro ela ocorre principalmente na faixa litorânea e Zona da Mata. O fruto do araçazeiro tem sabor que lembra o da goiaba, ligeiramente mais ácido e de perfume mais acentuado, e sua exploração é feita de modo extrativista. As informações sobre esta espécie são escassas, o que dificulta a conservação dos recursos genéticos e sua exploração econômica. Neste trabalho foram estudadas a diversidade e estrutura genética de quatro populações de araçá, tendo sido avaliados um total de 114 indivíduos por meio de 18 loci isoenzimáticos que revelaram 28 alelos. A porcentagem de locipolimórficos $(\widehat{\mathcal{P}})$ e o número médio de alelos por loco $(\widehat{A})$ nas populações foram 0,5 e 1,5 , respectivamente. A heterozigosidade esperada $\left(\widehat{H}_{\sigma}\right)$, que corresponde à diversidade gênica, variou entre 0,22 e 0,23 , valores altos, principalmenteconsiderando-se que isoenzimas acessam a porção funcional do genoma. $\mathrm{O}$ índice médio de diferenciação $\left(\widehat{\theta}_{p}\right)$ entre as populações foi de 0,015 , portanto, as populações basicamente não diferem entre os locais amostrados. O índice de fixação $(\tilde{f})$ variou de $-0,549$ a $-0,794$ indicando ausência de endogamia e excesso de heterozigosidade nas populações. O fluxo gênico $\left(N_{m}\right)$ estimado para os pares de populações variou de 3,23 a 20,77, valores que corroboram com a ausência de diferenciação observada entre estas.

Palavras chave: Recurso genético. Isoenzima. Fruteira nativa. Fluxo gênico.

\footnotetext{
${ }^{*}$ Corresponding author

${ }^{1}$ Received for publication in $06 / 18 / 2014$; accepted in $12 / 16 / 2015$.

Paper extracted from the masters dissertation of the second author.

${ }^{2}$ Department of Biology, Universidade Federal Rural de Pernambuco, Recife, PE, Brazil; silvaedsonf@hotmail.com, rafaelap6@hotmail.com, crisribeiro@hotmail.com, luizasemen@gmail.com.

${ }^{3}$ Department of Genetic, Escola Superior de Agricultura Luiz de Queiroz, Universidade de São Paulo, Piracicaba, SP, Brazil; eaveasey@usp.br.
} 


\section{INTRODUCTION}

Psidium guineense SW., popularly known as araçá, belongs to the Myrtaceae family, which includes approximately 100 genera and 3000 species, including trees and shrubs, and is distributed on all continents except Antarctica; it occurs more often in tropical and subtropical regions (PEREIRA; NACHTIGAL, 2003).

This specie is originally from South America (BRANDÃO et al., 2002), and in Brazil occurs spontaneously from the Rio Grande do Sul to the Amazon, mainly in coastal areas (BEZERRA et al., 2006). In northeastern Brazil, P. guineense occurs along the seaside and Zona da Mata, principally in coastal board areas (DEMATTÊ, 1997; BALOCH et al., 2006) and the Semi-arid region of Bahia (QUEIROZ, 2011; SANTOS et al., 2014).

$P$. guineense is a shrub with stature from 2.0 to $2.5 \mathrm{~m}$ and stem with smooth bark that peels off. Their fruits are similar to those of the guava but are smaller, more acidic, stronger smelling, globular (sometimes ovoid), pedunculated, and clear-yellow when ripe with a cream-colored pulp and many seeds (GONZÁLEZ et al., 2005). P. guineense fruit is accepted by consumers, who appreciate its exotic flavor and high $\mathrm{C}$ vitamin content (RASEIRA and RASEIRA, 1996); however, exploration performed through the extractivism (BEZERRA et al., 2006).

$P$. guineense has great importance as a genetic resource to be exploited directly in the prebreeding process or as a source of genes to transfer to the guava, Psidium guajava L., by conventional crossing. Nematode gall-resistant genotypes of $P$. guineense reportedly showed promise as grafts to guava (CASTRO et al., 2012; MARTINS et al., 2013).

The conserved genetic resources of $P$. guineense are little, especially considering the wide geographic distribution of the species. The accessions of this species are maintained in collections with other species of the Psidium genus, including cultivated species of P. guajava, according to Bezerra (2006), Santos et al. (2008), and Queiroz (2011). There is little information about the diversity and genetic structure of natural populations of $P$. guineense; however, severe genetic erosion is assumed due to the devastation of ecosystems where the species occurs, as registered with other fruit native species.

Therefore, studies of the diversity and genetic structure of natural populations are very important because they could provide fundamental parameters for pre-breeding and define conservation strategies, especially those that guarantee the continuity of the evolutionary process of populations over time (RAU; HODGKIM, 2002).

Using molecular markers can get parameters on the structure and genetic diversity of populations, as well as estimate gene flow among populations (HAMRICK, 1982). Isoenzyme markers have been used in many studies of natural populations because isoenzymes access information from the functional genome and are codominant. Applying these markers were studied populations of several tropical fruits, such as cagaiteira (Eugenia dysenterica DC.) (TELLES et al., 2001), araticunzeiro (Annona crassiflora Mart.) (TELLES et al., 2003), genipapo (Genipa americana L.) (SEBBENN et al., 2003), pequizeiro (Caryocar brasiliense Camb.) (MELO JÚNIOR et al., 2004), cajazeira (Spondias mobin L.) (SILVA et al., 2009), mangabeira (Hancornia speciosa var. speciosa Gomes) (MARTINS et al., 2012), and other species of ecological interest.

The objective of this work was to study the diversity and genetic structure of four populations of araçá in Zona da Mata region of Pernambuco State using isoenzymatic markers, in order to provide information for use in conservation and pre-breeding programs.

\section{MATERIAL AND METHODS}

\section{Sampling}

Four natural populations of $P$. guineense, named Itamaracá, Marieta, Arariba, and Palmares, located in the municipalities of Itamaracá, Moreno, Escada, and Palmares, respectively, corresponding to the coastal lowland of the State of Pernambuco, were studied (Table 1). The Itamaracá population occurred in clearings of the remnant vegetation of the Atlantic Forest and the individuals showed different ages. The other three populations occurred in areas where sugar cane was previously cultivated, where soil conditions seemed to favor the development of the plants. The plants seemed to have similar ages, and according to reports from local people, the populations were established for around seven to 11 years.

Random sampling was conducted to accurately represent plant density and population sizes. The young leaves of sampled individuals were collected, placed in plastic bags, kept in an ice cooler, and carried to the Genetics Population Laboratory of the Biology Department of the Federal Rural University of Pernambuco, where they were stored in at $-80^{\circ} \mathrm{C}$ until isoenzyme extraction. 
E. F. SILVA et al.

Table 1. Identification of araçá ( $P$. guineense) populations studied in Pernambuco state.

\begin{tabular}{|c|c|c|c|c|}
\hline \multirow[b]{2}{*}{ Municipalities } & \multirow[t]{2}{*}{ Populations } & \multirow[b]{2}{*}{$\mathrm{n}^{*}$} & \multicolumn{2}{|c|}{ Geographical coordinates } \\
\hline & & & Larger and smaller Latitude & Larger and smaller Longitude \\
\hline Itamaracá & Itamaracá & 28 & $07^{\circ} 44^{\prime} 197^{\prime \prime}$ a 07-44'989', & $034^{\mathrm{o}} 51^{\prime} 312^{\prime \prime}$ a 034은 $51^{\prime} 667^{\prime \prime}$ \\
\hline Moreno & Marieta & 30 & $08^{\mathrm{o}} 07^{\prime} 113^{\prime \prime}$, a $08^{\mathrm{o}} 08^{\prime} 965^{\prime}$, & $035^{\circ} 10^{\prime} 986^{\prime \prime}$ a $035^{\circ} 11$ '171', \\
\hline Escada & Arariba & 28 & $08^{\circ} 16^{\prime} 017^{\prime \prime}$ ' a $08^{\circ} 17^{\prime} 968^{\prime \prime}$, & $035^{\circ} 08^{\prime} 721^{\prime \prime}$ a $035^{\circ} 11^{\prime} 196$ ', \\
\hline Palmares & Palmares & 28 & $08^{\circ} 43^{\prime} 266^{\prime \prime}$ a $08^{\circ} 46^{\prime} 179^{\prime \prime}$ & $035^{\circ} 31^{\prime} 013^{\prime}$ ', a $035^{\circ} 31^{\prime} 985^{\prime}$, \\
\hline
\end{tabular}

$\mathrm{n}^{*}=$ number of individuals sampled

Twenty-eight to 30 individuals in each population were sampled, according to the abundance of plants and population size, in the period of January to April 2013. The minimum distance between sampled individuals was 50 meters to minimize the probability of collecting sister plants. Each tree was identified by a numbered aluminum label and georeferenced using a Global Positioning System (GPS) to facilitate if necessary, resampling or the collection of propagative parts.

\section{Extraction and revelation of enzymes}

The enzymes were extracted using the buffer no. 1 of Alfenas et al. (1998), and PVP40 (Polyvinylpyrrolidone) was added during leaf maceration. The obtained samples were stored at $80^{\circ} \mathrm{C}$ until the isozymes were separated by horizontal electrophoresis on $13 \%$ starch gels, according to the method of Alfenas et al. (1998). The gel/electrode buffer systems used were: TCP (TrisBorate, Citrate, $\mathrm{pH}$ 7.5) and LB (Lithium Borate, $\mathrm{pH}$ $8.5)$.

A total of 18 enzyme systems were tested to provide more informative band patterns: esterase EST, shikimate dehydrogenase - SKDH, catalase CAT, alcohol dehydrogenase - $\mathrm{ADH}$, 6phosphogluconate dehydrogenase - 6-PGDH, Leucine aminopeptidase - LAP, Isocitrate dehydrogenase - IDH, malate dehydrogenase $\mathrm{MDH}$, acid phosphatase - ACP, peroxidase - PO, glucose 6-phosphate dehydrogenase - G6PDH, isoglucose isomerase - PGI, phosphoglucomutase PGM, malic enzyme - ME, glutamate oxaloacetate transaminase - GOT, polyphenol oxidase - PPO, superoxide dismutase - SOD, and alkaline phosphatase - AKP.

\section{Data analysis}

Zymograms were interpreted using allele frequencies and diversity indices, such as: percentage of polymorphic loci $(\widehat{P})$, estimated by the ratio of the average of number of polymorphic loci and the total number of loci, considering loci whose frequency of the most common polymorphic alleles did not exceed 95\%; average number of alleles by locus $(\hat{A})$, obtained by dividing the total number of alleles by the total number of loci; observed heterozygosity $\left(\widehat{H}_{0}\right)$, which was obtained by the equation $\hat{H}_{0}=1-\sum p_{\mathrm{ii}}$, where ${ }^{p_{\mathrm{ii}}}=$ frequency of homozygous genotypes; expected heterozygosity $\left(\widehat{H}_{e}\right)$, obtained by the equation $\hat{H}_{a}=1-\Sigma p_{\mathrm{i}}^{2}$, where $p_{\mathrm{i}}=$ allele frequency estimated the ith allele; and index $(\hat{f})$, estimated by the equation $\hat{f}=1-\left(\hat{H}_{0} / \hat{H}_{\varepsilon}\right)$. The effective size $\left(N_{e}\right)$ was estimated as reported by Vencovsky (1992), i.e., ${ }^{N_{\theta}}=(n / 1+\widehat{f})$, where $n$ is the number of sampled plants and $\hat{f}_{\text {is }}$ the population inbreeding coefficient.

The estimated parameters of the genetic structure of the population were: unbiased genetic divergence among populations $\left(F_{S T}\right)$, according to Nei (1978); genetic identity (GI); and estimates of the gene flow among populations, according to the method of Crow and Aoki (1984), which followed the equation: $N_{s m}=\left[\left(\frac{1}{s_{s T}}\right)-1\right] / 4 \propto, \quad$ where $\propto=[n /(n-1)]^{2}$, and $N_{m}=$ number of migrants per generation, $n$ the number of populations, and $F_{S T}$ is genetic divergence among populations. The coancestry coefficients were estimated using the method of Cockerham (1969), i.e., using confidence intervals with $95 \%$ probability and the bootstrap resampling method with 10000 repetitions per locus. All analyses were performed using the GDA software program (LEWIS; ZAYKIN, 2000).

\section{RESULTS AND DISCUSSION}

From the 18 isoenzymatic systems tested, nine revealed band patterns on all individuals of the four studied populations, which were used for analysis (Table 2). The nine systems showed 18 loci and 28 alleles. The ACP1, EST1, GOT1, GOT2, PGI1, SKDH1, 6-PGDH1, and AKP1 loci revealed only one allele that was present in the four studied populations. The other loci (LAP1, LAP2, ACP2, 
EST2, PGI2, 6PGDH2, AKP2, ASK2, ADH1, and $\mathrm{ADH} 2$ ) revealed two alleles each, with frequencies ranging from 0.017 to 1,000 , showing variation among and within populations.

Changes in allele frequencies in finite populations can indicate genetic drift resulting from gamete sampling in each generation (HEDRINK, 2005). Analyses of allele frequencies are of great importance because they reflect the stochastic effects better than most of the other parameters used in studies of population genetics (BOTREL and CARVALHO, 2004). In the Arariba, Marieta, and Palmares populations, the changes in allele frequencies may be more associated with genetic drift because the populations are new, formed after the interruption of sugar cane cultivation in areas of steep topography; in contrast, in the Itamaracá population, the glades are open and booked sporadically because of anthropic action and due to the regeneration of the vegetation by secondary and tertiary plants that restrict the permanence of $P$. guineense, and therefore young plants are the most prevalent.

Table 2. Frequency of alleles observed at each locus in the four populations of araçá ( $P$. guineense) studied.

\begin{tabular}{|c|c|c|c|c|c|}
\hline \multirow[b]{2}{*}{ Loco } & \multicolumn{5}{|c|}{ Populations } \\
\hline & Alleles & Itamaracá & Marieta & Arariba & Palmares \\
\hline Acp 1 & 1 & 1.000 & 1.000 & 1.000 & 1.000 \\
\hline \multirow[t]{2}{*}{ Acp 2} & 1 & 0.607 & 0.600 & 0.428 & 0.535 \\
\hline & 2 & 0.392 & 0.400 & 0.571 & 0.464 \\
\hline \multirow[t]{2}{*}{ Lapl } & 1 & 1.000 & 0.648 & 0.875 & 0.818 \\
\hline & 2 & 0.000 & 0.351 & 0.125 & 0.181 \\
\hline \multirow[t]{2}{*}{ Lap2 } & 1 & 0.660 & 0.616 & 0.500 & 0.410 \\
\hline & 2 & 0.339 & 0.383 & 0.500 & 0.589 \\
\hline Est 1 & 1 & 1.000 & 1.000 & 1.000 & 1.000 \\
\hline \multirow[t]{2}{*}{ Est2 } & 1 & 0.464 & 0.150 & 0.303 & 0.500 \\
\hline & 2 & 0.535 & 0.850 & 0.696 & 0.500 \\
\hline Got 1 & 1 & 1.000 & 1.000 & 1.000 & 1.000 \\
\hline Got2 & 1 & 1.000 & 1.000 & 1.000 & 1.000 \\
\hline Pgil & 1 & 1.000 & 1.000 & 1.000 & 1.000 \\
\hline \multirow[t]{2}{*}{ Pgi2 } & 1 & 0.500 & 0.766 & 0.410 & 0.607 \\
\hline & 2 & 0.500 & 0.233 & 0.589 & 0.392 \\
\hline Skdhl & 1 & 1.000 & 1.000 & 1.000 & 1.000 \\
\hline \multirow[t]{2}{*}{ Skdh2 } & 1 & 0.500 & 0.483 & 0.500 & 0.500 \\
\hline & 2 & 0.500 & 0.516 & 0.500 & 0.500 \\
\hline $6 P g d h 1$ & 1 & 1.000 & 1.000 & 1.000 & 1.000 \\
\hline \multirow[t]{2}{*}{ 6Pgdh 2} & 1 & 0.500 & 0.350 & 0.500 & 0.589 \\
\hline & 2 & 0.500 & 0.650 & 0.500 & 0.410 \\
\hline Akp 1 & 1 & 1.000 & 1.000 & 1.000 & 1.000 \\
\hline \multirow[t]{2}{*}{ Akp2 } & 1 & 0.410 & 0.350 & 0.464 & 0.392 \\
\hline & 2 & 0.589 & 0.650 & 0.535 & 0.607 \\
\hline \multirow[t]{2}{*}{ Adhl } & 1 & 0.982 & 1.000 & 1.000 & 1.000 \\
\hline & 2 & 0.017 & 0.000 & 0.000 & 0.000 \\
\hline \multirow[t]{2}{*}{ Adh 2} & 1 & 0.410 & 0.500 & 0.500 & 0.456 \\
\hline & 2 & 0.589 & 0.500 & 0.500 & 0.543 \\
\hline
\end{tabular}


The percentage of polymorphic loci $(\hat{P})$ was 0.5 , and the average number of alleles per locus (A) was 1.5 (Table 3 ). The regularity of these parameters can be associated with the characteristics of this species, which behaves as a pioneer in the Zona da Mata area of Pernambuco and shows the capability of establishing itself in areas where sugar cane cultivation was disrupted. As the populations are new, only seven to 11 years old, not enough time has passed for selective factors to work in the populations. The behavior of $P$. guineense as a pioneering plant was reported by Barnett et al. (2002). Furthermore, one should also consider that the primary dispersal mode of this species is by birds carrying the seeds, which usually have large displacements and probably are the same birds that disseminate guava seed because all araçá populations occur with guava plants (ARAÚJO, 2014).

Table 3. diversity index in studied populations of araça ( $P$. guineense) based on the 18 allozyme loci.

\begin{tabular}{ccccccccc}
\hline População & $\mathrm{n}$ & $\mathrm{P}$ & $\hat{A}$ & $\widehat{H}_{0}$ & $\widehat{H}_{e}$ & $\hat{f}$ & $N e$ & $N e / n$ \\
\hline Itamaracá & 28 & 0.50 & 1.50 & 0.39 & 0.22 & -0.794 & 135.92 & 4.85 \\
Marieta & 30 & 0.50 & 1.50 & 0.34 & 0.22 & -0.549 & 66.52 & 2.22 \\
Arariba & 28 & 0.50 & 1.50 & 0.40 & 0.23 & -0.754 & 113.82 & 4.06 \\
Palmares & 28 & 0.50 & 1.50 & 0.39 & 0.23 & -0.678 & 86.96 & 3.10 \\
\hline Média & 28,5 & 0.50 & 1.50 & 0.38 & 0.22 & -0.693 & 100.80 & 3.54 \\
\hline
\end{tabular}

Number of individuals sampled in each population (n), percentage of polymorphic loci (P), average of allele per locus number $(\hat{A})$, observed heterozygosity $\left(\hat{H}_{0}\right)$, expected heterozygosity $\left(\hat{H}_{s}\right)$, fixation index $(\hat{f})$, effective size $(\mathrm{Ne})$, and relationship between effective size and real size $(\mathrm{Ne} / \mathrm{n})$

The average observed heterozygosity $\left(\widehat{H}_{0}\right)$, which ranged from 0.34 to 0.40 , and the average expected heterozygosity $\left(\widehat{H}_{\varepsilon}\right)$, which corresponds to the gene diversity, basically did not vary, with values from 0.22 to 0.23 (Table 3); Itamaracá and Marieta had the same value (0.22) and Araiba and Palmares had the same value (0.23). Therefore, more heterozygotes were observed than expected by the Hardy-Weinberg Equilibrium. This diversity level (from 22 to $23 \%$ ) is considered high or intermediate in population studies of isoenzymes, mainly considering that isozyme markers use the functional portion of the genome; other isoenzyme-based studies of wild species populations showed similar diversity values. Kageyama et al. (2003) obtained $\widetilde{H}_{\varepsilon}$ values that ranged from 0.255 to 0.480 for five forest species (Trema micrantha, Cecropia pachystachya, Cariniana legalis, Maytenus aquifolia, and Esenbeckia leiocarpa) in different successional phases. Martins-Corder et al. (2009) obtained values that ranged from 0.203 to 0.276 to Euterpe edulis Martius, under three different environmental conditions. Martins et al. (2012) observed values from 0.300 to 0.420 when studying Hancornia speciosa variety speciosa in northeastern Brazil. The genetic diversity and absence of differentiation observed among populations of $P$. guineense in the Zona da Mata of Pernambuco State indicate that, for germplasm conservation or to perform comparison studies with materials from other areas, only one of the studied populations is necessary to represent this region.

The fixation index $(\hat{f})$ ranged from -0.549 to 0.794 (Table 3). Negative values indicate high heterozygosity, according to $\hat{H}_{0}$, and the obtained $\hat{H}_{e}$ values suggested natural reproduction by allogamy. High levels of genetic diversity provide a large number of combination genotypes in sexuallyreproducing species, which increases the evolutionary potential as a consequence of the great adaptability to environmental changes (SEBBENN et al., 2000). The observed uniform diversity of the four studied populations can also be related to the pioneering behavior of $P$. guineense that promotes the founding of plant populations with similar ages. Furthermore, because $P$. guineense is dispersed mainly by birds, with distances between populations ranging from 16 to $130.3 \mathrm{~km}$ (Table 4), these populations could be created by seeds of the same origin, principally the Arariba, Marieta, and Palmares populations.

The genetic differentiation among populations $\left(F_{S T}\right)$ and genetic identity $(\mathrm{GI})$ in pairs of populations (Table 4) showed that there is no difference between populations. Indirect estimates of gene flow $(\mathrm{Nm})$ showed values that ranged from 3.23 to 20.77 (Table 4), considered high and sufficient to avoid differentiation among populations; according to Elltsrad (2003), values higher than 1.0 prevent genetic differentiation among the four studied populations. These results indicate that all the studied populations are representatives to ex situ or in situ conservation, as well as to perform in situ conservation because the four have the same representative genetic potential. 
Table 4. Genetic identity $(G I)$, estimated genetic differentiation $\left(F_{S T}\right)$ according to Nei (1978), geographical distance, and gene flow $(\mathrm{Nm})$ for each pair of population of araçá (P. guineense) in the Zona da Mata of Pernambuco.

\begin{tabular}{ccccc}
\hline Combinations & $G I$ & $F_{S T}$ & $\begin{array}{c}\text { Geographical distance } \\
(\mathrm{km})\end{array}$ & $\mathrm{Nm}$ \\
& & & 72.7 & 20.77 \\
Itamaracá x Arariba & 0.997 & 0.003 & 56.1 & 3.23 \\
Itamaracá x Marieta & 0.981 & 0.019 & 130.3 & 20.77 \\
Itamaracá x Palmares & 0.997 & 0.003 & 57.6 & 20.77 \\
Palmares x Arariba & 0.997 & 0.003 & 74.2 & 4.10 \\
Palmares x Marieta & 0.985 & 0.015 & 16.6 & 4.10 \\
Marieta x Arariba & 0.985 & 0.015 & & \\
\hline
\end{tabular}

The genetic differentiation among populations $\left(F_{S T}\right)$ and genetic identity (GI) in pairs of populations (Table 4) showed that there is no difference between populations. Indirect estimates of gene flow $(\mathrm{Nm})$ showed values that ranged from 3.23 to 20.77 (Table 4), considered high and sufficient to avoid differentiation among

populations; according to Elltsrad (2003), values higher than 1.0 prevent genetic differentiation among the four studied populations. These results indicate that all the studied populations are representatives to ex situ or in situ conservation, as well as to perform in situ conservation because the four have the same representative genetic potential.

Table 5. Average inbreeding for each locus in all populations $(\hat{F})$, average of inbreeding for each locus within populations $\left({ }^{(}\right)$, and coefficient of coancestrality $\left({ }^{{ }^{*}}\right)$ in four natural populations of $P$. guineense on 18 allozyme loci.

\begin{tabular}{|c|c|c|c|}
\hline Loci & $\widehat{F}$ & $\hat{f}$ & $\hat{\theta}_{p}$ \\
\hline Acpl & -0.615 & -0.690 & 0.044 \\
\hline Acp 2 & -0.610 & -0.690 & 0.050 \\
\hline Lap1 & -0.654 & -0.720 & 0.040 \\
\hline Lap2 & -0.622 & -0.600 & 0.044 \\
\hline Est 1 & -0.615 & -0.690 & 0.044 \\
\hline Est2 & -0.630 & -0.690 & 0.036 \\
\hline Got1 & -0.615 & -0.690 & 0.044 \\
\hline Got 2 & -0.615 & -0.690 & 0.044 \\
\hline Pgil & -0.615 & -0.690 & 0.044 \\
\hline Pgi2 & -0.627 & -0.691 & 0.038 \\
\hline Skdh1 & -0.615 & -0.690 & 0.044 \\
\hline Skdh2 & -0.566 & -0.650 & 0.050 \\
\hline $6 P g d h 1$ & -0.615 & -0.690 & 0.044 \\
\hline $6 P g d h 2$ & -0.619 & -0.696 & 0.045 \\
\hline Akpl & -0.615 & -0.690 & 0.044 \\
\hline Akp2 & -0.621 & -0.705 & 0.050 \\
\hline Adhl & -0.616 & -0.691 & 0.044 \\
\hline Adh2 & -0.580 & -0.662 & 0.050 \\
\hline Média & -0.691 & -0.617 & 0.015 \\
\hline
\end{tabular}


The average estimates of the coancestry coefficients of Cockerham (1969) showed the absence of inbreeding for the populations $(\widehat{\boldsymbol{F}}=$ 0.691 ) and excess heterozygosity within these populations $(\hat{f}=-0.617)$, confirming the tendency of populations toward allogamy (Table 5). Inbreeding due to genetic drift, by a foundation effect from a small number of individuals, may occur because of the fixation of deleterious alleles, causing inbreeding depression and reducing the adaptability of species in cases where overdominance gene interaction prevails (FRANKHAM et al., 2006).

The average divergence among populations $\left(\hat{\theta}_{p}\right)$ was very low $(1.5 \%)$ (Table 5$)$, confirming the $F_{S T}$ parameter results, and seems to be a specific characteristic of $P$. guineense due to its dispersion mode, allogamy reproduction system, and pioneer specie status.

The genetic representativeness of individuals evaluated by estimating the effective population size (Ne) showed estimated values higher than the number of individuals sampled (Table 3), confirming the absence of inbreeding in the populations. According to Moraes and Derbyshire (2002), this parameter evaluates the impact due to genetic drift. Table 3 also shows the relationship between the effective size and the actual population size $(\mathrm{Ne} / \mathrm{n})$, which allows the estimation of the minimum viable population size needed to maintain the population's genetic integrity. According to Raposo et al. (2007), this relationship is fundamental to establishing conservation strategies.

\section{CONCLUSIONS}

The araçá ( $P$. guineense) populations at the Zona da Mata of Pernambuco are not different from one another in terms of genetic diversity.

The genetic diversity within populations of araçá in the Zona da Mata of Pernambuco is high.

There is no restriction on gene flow among araçá populations in the Zona da Mata of Pernambuco, sufficient for avoiding differentiation among then.

The absence of endogamy in populations suggests that reproduction predominantly occurs by allogamy in $P$. guineense in the Zona da Mata of Pernambuco.

\section{REFERENCES}

ALFENAS, A.C. Eletroforese de isoenzimas e proteínas afins: fundamentos e aplicações em plantas e microorganismos. 1. ed. Viçosa, MG: UFV, 1998. $574 \mathrm{p}$.

ARAÚJO, R. L. Diversidade e estrutura genética de populações naturais de araçá (Psidium guineense Sw.) no Estado de Pernambuco. 2014. 51 f. Dissertação (Mestrado em Agronomia: Área de Concentração em Melhoramento Genético de Plantas) - Universidade Federal Rural de Pernambuco, Recife, 2014.

BEZERRA, J. E. F. et al. Araçá. In: VIEIRA, R. F. et al. (Ed.). Frutas nativas da região Centro-Oeste do Brasil. Brasília, DF: Embrapa Recursos Genéticos e Biotecnologia, 2006. v. 1, cap. 03, p. 4262 .

BOTREL, M. C. G.; CARVALHO, D. Variabilidade genética em populações naturais de jacarandá paulista (Machaerium villosum Vog.). Revista Brasileira de Botânica, São Paulo, v. 27, n. 4, p. 621-627, 2004.

BRANDÃO, M.; LACA-BUENDÍA, J. P.; MACEDO, J. F. Árvores nativas e exóticas do estado de Minas Gerais. 1. ed. Belo Horizonte, MG: EPAMIG, 2002. 528 p.

CASTRO, J. M. C. et al. Reaction of Psidium accessions to Meloidogyne enterolobii Root-Knot nematode. Acta Horticulturae, Leuve, n. 959, p. 5159,2012 .

COCKERHAM, C. C. Variance of gene frequencies. Evolution, Lancaster, v. 23, n. 1, p. 72-84, 1969.

CROW, J. F.; AOKI, K. Group selection for polygenic behavioral trait; estimating the degree of population subdivision. Proceeding of Natural Academy of Sciences USA, New York, v. 81, n. 19, p. $6073-6077,1984$.

DEMATTÊ, M. E. R. P. Ornamental use of Brazilian Myrtaceae. Acta Horticulturae, The Hague, n. 452, p. 143-179, 1997.

ELLTSRAD, N. C. Current knowledge of gene flow in plants: implications for transgene flow. Philosoph -ical Transactions of the Royal Society of London, London, v. 358, n. 1434, p. 1163-1170, 2003.

FRANKHAM, R.; BALLOU, J. D.; BRISCOE, D. A. Introdution to conservation genetics, 6 . ed. New York, NY: Cambridge University Press, 2006. $617 \mathrm{p}$.

HAMRICK, J. L. Plant population genetics and evolution. American Journal of Botany, Columbus, v. 69, n. 10, p. $1685-1693,1982$.

HEDRICK, P. W. Genetics of populations. 3 ed. Boston, MA: Jones and Bartlett Publishers, 2005, $737 \mathrm{p}$. 
KAGEYAMA, P. Y. et al. Diversidade genética em espécies arbóreas tropicais de diferentes estagio sucessionais por marcadores genéticos. Scientia Forestalis, Piracicaba, n. 64, p. 93-107, 2003.

LEWIS, P. O.; ZAYKIN, D. Genetic data analysis: computer program for the analysis of allelic data. Version 1.0. Disponível em: <http:// alleyn.eeb.uconn.edu/gda/2000>. Acessado em dezembro 2013.

MARTINS, G. V. et al. Diversity and genetic structure in natural populations of Hancornia speciosa var. speciosa Gomes in northeastern Brazil. Revista Brasileira de Fruticultura, Jaboticabal, v. 34, n. 4, p. 1143-1153, 2012.

MARTINS, L. S. S. et al. Parasitismo de Meloidogyne enterolobii em espécies de Myrtaceae. Revista Brasileira de Fruticultura, Jaboticabal, v. 35, n. 2, p. 477-484, 2013.

MARTINS-CORDER, M. P. et al. Análise da diversidade genética de populações de palmiteiro (Euterpe edulis Martius) através de marcadores isoenzimáticos. Ceres, Viçosa, v. 56, n. 2, p. 204206, 2009.

MELO JUNIOR, A. F. et al. Estrutura genética de populações naturais de pequizeiro (Caryocar brasiliense Camb). Scientia Forestalis, Piracicaba, n. 66, p. 56-65, 2004 .

MORAES, P. L. R.; DERBYSHIRE, M. T. V. C. Estrutura genética de populações naturais de Cryptocarya aschersoniana Mez (Lauraceae) através de marca-dores isoenzimáticos. Biota Neotropica, São Paulo, v. 2, n. 2, p. 1-19, 2002.

NEI, M. Estimation of average heterozygosity and genetic distance from a small number of individuals. Genetics, Bethesda, v. 89, n. 3, p. 583-590, 1978.

PEREIRA, F. M.; NACHTIGAL, J. C. Melhoramento da goiabeira. In: Bruckner C. H. Melhoramento de Fruteiras Tropicais (ed.), Viçosa, MG: UFV, p. 267-289.

QUEIROZ, M. A. Recursos genéticos vegetais da Caatinga para o desenvolvimento do Semiárido brasileiro. Revista Brasileira de Geografia Física, Recife, n. 6, p. 1135-1150, 2011.

RAO, R. V.; HODGKIM, T. Genetic diversity and conservation and utilization of genetic resources. Plant Cell, Waterbuty, v. 68, n. 1, p. 1-19, 2002.

RAPOSO, A. et al. Diversidade ge-nética de populações de andiroba no Baixo Acre. Pesquisa Agropecuária Brasileira, Brasília, v. 42, n. 9, p.
1291-1298, 2007.

RASEIRA, M. do C. B.; RASEIRA, A. Contribuição ao estudo do Araçá (Psidium cattleyanum). 1. ed. Pelotas, RS: Embrapa Clima Temperado, 1996. $95 \mathrm{p}$

SANTOS, M. A. et al. Diversidade genética entre acessos de araçá de diferentes municípios do Semiárido baiano. Revista Caatinga, Mossoró, v. 27, n. 2, p. 48-57, 2014

SEBBENN, A. M.; KAGEYAMA, P. Y.; VENCOVSKY, R. Conservação genética in situ e número de matrizes para a coleta de sementes em população de Genipa americana L. Scientia Forestalis, Piracicaba, n. 63, p. 13-22 2003.

SEBBENN, A. M. et al. Sistema de cruzamento em populações de Cariniana legalis Mart. O. Ktze.: implicações para a conservação e o melhoramento genético. Scientia Forestalis, Piracicaba, n. 58, p. 25 $-40,2000$.

SILVA, E. F.; MARTINS, L. S. S.; OLIVEIRA, V. R. Diversity and genetic struture in caja tree (Spondias mombin L.) populations in Northeastern Brazil. Revista Brasileira de Fruticultura, Jaboticabal, v. 31, n. 1 p. 171-181, 2009.

TELLES, M. P. C. et al. Caracterização genética de populações naturais de araticunzeiro (Annona crassiflora Mart. - Annonaceae) no Estado de Goiás. Revista Brasileira de Botânica, São Paulo, v. 26, n. 1, p. 123-129, 2003.

TELLES, M. P. C. et al. Divergência entre subpopulações de cagaiteira (Eugenia dysenterica) em resposta a padrões edáficos e distribuição espacial. Pesquisa Agropecuária Brasileira, Brasília, v. 36, n. 11, p. 1387-1394, 2001.

VENCOVSKY, R. Análise de variância de frequências alélicas. Revista Brasileira de Genética, Ribeirão Preto, v. 15, n. 1, p. 53-60, 1992. 